\title{
Differences in the Effects of Metals on Growth of Two Freshwater Green Algae (Pseudokirchneriella subcapitata (Korshikov) Hindak and Gonium pectorale Müller)
}

\author{
M. J. Pereira, ${ }^{1}$ P. Resende, ${ }^{1}$ U. M. Azeiteiro, ${ }^{2}$ J. Oliveira, ${ }^{1}$ \\ D. R. de Figueiredo ${ }^{1}$ \\ ${ }^{1}$ Biology Department, University of Aveiro, 3810-193 Aveiro, Portugal \\ 2 IMAR - Institute of Marine Research, University of Coimbra, 3000 Coimbra, Portugal
}

Natural erosion and the anthropogenic activity (agricultural, urban or industrial) are greatly responsible for the environmental heavy metals concentrations, namely of $\mathrm{Cd}, \mathrm{Cr}, \mathrm{Pb}$ and $\mathrm{Hg}$ (de Filippis and Pallaghy 1994; Wei et al. 2003). By contrast to pesticides and other pollutants, heavy metals do not break down in aquatic environments and so they persist in sediments or/and in particles in suspension, being slowly released into the water and becoming available to the organisms. But the heavy metals bioavailability and toxicity potential are controlled by metal speciation in water (Meylan et al. 2003). Physico-chemical characteristics such as $\mathrm{pH}$, redox potential, temperature, ionic content, mineral particles, organic matter and light may influence metals chemical form and their mobility and availability (de Filippis and Pallaghy 1994). The uptake of some metals by microalgae has been reported to be sensitive to $\mathrm{pH}$ variations and the presence of humic substances (Boullement et al. 2004). Thus, chemical (dissolution, redox reactions and (de)sorption compounds), physical (flows and tides) and biological processes (microbial degradation and bioturbation) are all important to determine metals bioavailability (Kennish 1992).

Environmental contamination with heavy metals may cause direct and/or indirect effects on terrestrial and aquatic ecosystems (Fleeger et al. 2003). There may be effects at the suborganismic (molecules, cells, tissues or organs) or/and superorganismic (individuals, populations or communities) levels resulting in a wide range of responses (Kennish 1992). In relation to biota metabolism, non essential metal ions (such as $\mathrm{Cd}, \mathrm{Pb}$ or $\mathrm{Cr}$ ) can inhibit a variety of metabolic processes, even in small quantities (Kennish 1992; Cervantes et al. 2001) but some essential metal ions (such as $\mathrm{Zn}$ or $\mathrm{Cu}$ ), when present at concentrations above a defined threshold may also become toxic (de Filippis and Pallaghy 1994; Campanella et al. 2001). Microalgae play an important role in aquatic ecosystems due to their position in the trophic chain (primary producers), making the aquatic biota of higher trophic levels dependent upon their photosynthetic activity. Perturbations in phytoplanktonic communities may also have severe repercussions throughout the food chain due to biomagnification (Kennish 1992; Campanella et al. 2001). The toxicity of a substance (such as a metal) is usually assessed by standard growth inhibition tests using standard species. Nevertheless, these standard species may not represent the environmental community sensitivity under

$\overline{\text { Correspondence to: }}$ M. J. Pereira 
the stress of the particular tested toxic compound. Thus, maybe toxicity tests should be conducted not only with one standard species but also with other species (including environmental-isolated ones) possessing different ecological characteristics (and potentially more sensitive) before concluding about the toxic levels of a certain compound. In the present study there were compared the differences in sensitivity, when exposed to high concentrations of some metals, of two selected freshwater green algae: Pseudokirchneriella subcapitata (Korshikov) Hindak, which is widely recommended (by EPA and OECD) as standard test organism in ecotoxicology, and the environmental-isolated Gonium pectorale Müller.

\section{MATERIALS AND METHODS}

In this study, two Chlorophyceae were chosen to test some metals impact on their growth: Pseudokirchneriella subcapitata (Korshikov) Hindak usually named Selenastrum capricornutum Printz (also known by Raphidocelis subcapitata Korshikov), which is a coccoid form, and Gonium pectorale Müller, which is a flagellate coenobium with 16 cells gathered by a transparent mucilaginous matrix. $P$. subcapitata was originally obtained from the Culture Collection of Algae (Tennessee, USA). G. pectorale Müller was isolated from water samples collected in a shallow lake of Central Portugal. Unialgal cultures of this alga were obtained by isolating a single colony with a micropipette under light microscope observation. Cultures were grown in $250 \mathrm{~mL}$ Erlenmeyers flasks with approximately $100 \mathrm{~mL}$ of synthetic culture medium with the following composition by litre: $40 \mathrm{mg}$ for $\mathrm{Ca}\left(\mathrm{NO}_{3}\right)_{2} .4 \mathrm{H}_{2} \mathrm{O}, \mathrm{MgSO}_{4} .7 \mathrm{H}_{2} \mathrm{O}$ and $\mathrm{K}_{2} \mathrm{HPO}_{4}$ each; $100 \mathrm{mg}$ of $\mathrm{KNO}_{3} ; 15 \mu \mathrm{g}$ of $\mathrm{CuSO}_{4} \cdot 5 \mathrm{H}_{2} \mathrm{O} ; 30 \mu \mathrm{g}$ of $\left(\mathrm{NH}_{4}\right)_{2} \mathrm{MoO}_{4} \cdot \mathrm{H}_{2} \mathrm{O}$, $\mathrm{ZnSO}_{4} .7 \mathrm{H}_{2} \mathrm{O}, \mathrm{CoCl}_{2} .6 \mathrm{H}_{2}, \mathrm{Mn}\left(\mathrm{NO}_{3}\right)_{2} .4 \mathrm{H}_{2} \mathrm{O}$, Citric acid and $\mathrm{H}_{3} \mathrm{BO}_{3}(\mathrm{pH}=6.8 \pm 0.1)$ each. Static cultures were maintained in a culture cabinet at $20 \pm 1^{\circ} \mathrm{C}$ and under an irradiance of $40 \mu \mathrm{E} \cdot \mathrm{m}^{-2} \cdot \mathrm{s}^{-1}$, provided by cool-white fluorescent lamps, with a light/dark cycle of $12 \mathrm{~h} / 12 \mathrm{~h}$. Growth curves for both species were established from daily cell counts using a Neubauer counting chamber. Mobile cells ( $G$. pectorale) were killed just before counting with a drop ( $50 \mu \mathrm{L}$ for $5 \mathrm{~mL}$ ) of Lugol solution.

For both algal species, three metals $\left(\mathrm{Cu}^{2+}, \mathrm{Cr}^{2+}\right.$ and $\left.\mathrm{Ni}^{2+}\right)$ were tested using Mili-Q water quality solutions prepared from the salts $\mathrm{Cu}\left(\mathrm{NO}_{3}\right)_{2}, \mathrm{CrSO}_{3} \mathrm{~K}_{2} \mathrm{SO}_{4} .24 \mathrm{H}_{2} \mathrm{O}$ and $\mathrm{NiCl}_{2} \cdot 6 \mathrm{H}_{2} \mathrm{O}$. Yet, for $G$. pectorale there were also performed tests using plus six metals $\left(\mathrm{Hg}^{2+}, \mathrm{Cd}^{2+}, \mathrm{Zn}^{2+}, \mathrm{Cr}_{2} \mathrm{O}_{7}^{2-}, \mathrm{Cs}^{+}\right.$and $\mathrm{Pb}^{2+}$ ) from solutions made of the following salts: $\mathrm{HgCl}_{2}, \mathrm{CdCl}_{2} \cdot \mathrm{H}_{2} \mathrm{O}, \mathrm{NiCl}_{2} \cdot 6 \mathrm{H}_{2} \mathrm{O}, \mathrm{Zn}\left(\mathrm{NO}_{3}\right)_{2}, \mathrm{~K}_{2} \mathrm{Cr}_{2} \mathrm{O}_{7}, \mathrm{CsCl}$ and $\mathrm{Pb}\left(\mathrm{NO}_{3}\right)_{2}$, respectively. For each metal, a different range of concentrations was tested (as determined by preliminary tests). Cells in the exponential growth phase were used in the algal experiments. The initial cell concentration in the tests was about $10^{4}$ cells.mL $\mathrm{m}^{-1}$. Static toxicity tests were conducted, in triplicate, during a period of $96 \mathrm{~h}$ in the same conditions described above for the algal maintenance procedure, but in $250 \mathrm{~mL}$ Erlenmeyer borosilicate glass flasks (to avoid the metals adsorption to the flasks (Andersen et al. 2002)) with $100 \mathrm{~mL}$ synthetic culture medium. Cells were quantified by direct counting as explained for the 
establishment of the growth curves. The results of toxicity tests based on the growth inhibition of the two algal species over $96 \mathrm{~h}$ were reported as $\mathrm{EC}_{50}$ (with $95 \%$ confidence intervals) derived using probit analysis. Variance analysis (ANOVA) was done to compare the results (expressed as percentage of the control cell number achieved at the end of the $96 \mathrm{~h}$ test period, in order to compare different growth ranges in the same graph) between control and exposed algae, followed by a Tukey multiple comparison test (Zar 1996).

\section{RESULTS AND DISCUSSION}

The growth curves obtained for both $P$. subcapitata and $G$. pectorale cultures after 14 days (Figure 1) show that $P$. subcapitata achieved almost a 10 -fold higher cell density $\left(7.97 \times 10^{6}\right.$ cells. $\left.\mathrm{mL}^{-1}\right)$ than $G$. pectorale $\left(0.82 \times 10^{6}\right.$ cells. $\left.\mathrm{mL}^{-1}\right)$. This could indicate an important aspect in the ecotoxicological tests by enhancement of the effects by the alga that achieved higher cell densities. But the differences found in the following results indicate more visible inhibiting effects in the alga that grew less ( $G$. pectorale). The results referring to the toxicity of the tested metals on growth of both green algae are summarized as $\mathrm{EC}_{50}$ values in Table 1 . For both species, the 16-fold growth at the end of the $96 \mathrm{~h}$ test period was assured in the control replicates and the following order of toxicity was achieved: $\mathrm{Cu}^{2+}>\mathrm{Ni}^{2+}>$ $\mathrm{Cr}^{2+}$ (Table 1 and Figures 2, 3 and 4) with copper showing the highest inhibitory effect on the algae cell division rate. Regarding $G$. pectorale the $\mathrm{EC}_{50}$ were derived as 0.088 (95\% confidence limits of 0.078-0.099), 0.669 (95\% confidence limits of $0.516-0.867$ ) and 0.794 (95\% confidence limits of $0.704-0.895) \mathrm{mg.L}^{-1}$ for $\mathrm{Cu}^{2+}, \mathrm{Ni}^{2+}$ and $\mathrm{Cr}^{2+}$, respectively. For $P$. subcapitata these values were 0.130 (95\% confidence limits of $0.074-0.228$ ), 1.070 (95\% confidence limits of 0.449 $2.275)$ and $2.079(95 \%$ confidence limits of $0.405-10.611) \mathrm{mg} . \mathrm{L}^{-1}$ for $\mathrm{Cu}^{2+}, \mathrm{Ni}^{2+}$ and $\mathrm{Cr}^{2+}$, respectively. Thus, the sensitivity of both species to the tested metals was found to be different, with the environmental isolated $G$, pectorale culture proving to be more sensitive (showing lower values of $96 \mathrm{hEC}_{50}$ ) than the laboratory standard $P$. subcapitata culture. $P$. subcapitata showed to be tolerant to approximately twice the $\mathrm{EC}_{50}$ concentrations determined for $G$. pectorale (Table 1). For copper, using $P$. subcapitata, significant differences in growth (comparing to $100 \%$ growth in the control) were only found for copper concentrations $\geq 1$ $\mathrm{mg} \cdot \mathrm{L}^{-1}$, while using $G$. pectorale a significant growth inhibition was found at $\geq 0.2$ mg. $L^{-1}$ (Figure 2). For both metals nickel and chromium, significant growth inhibition was found to occur at $\geq 10 \mathrm{mg} . \mathrm{L}^{-1}$ for $P$. subcapitata but at $\geq 0.5 \mathrm{mg} \cdot \mathrm{L}^{-1}$ for $G$. pectorale (Figures 3 and 4). The structure and productivity of the aquatic ecosystems depend on the concentration and form of various trace metals. Some trace elements increase the growth rate of some algal species, but have no effect on other algal species due to interspecific differences (Shehata and Badr 1980; Yan et al. 2002). Thus, in the evaluation of heavy metals toxicity towards microalgae it is important to consider interspecific differences concerning sensibility (Rojíčková and Maršálek 1999; Yan et al. 2002). In laboratory experiments, environmental factors can be controlled and the toxicological response of organisms to the same pollutant may be different if we use test species collected from the environment and other test species acclimated to laboratory environment due to their previous 


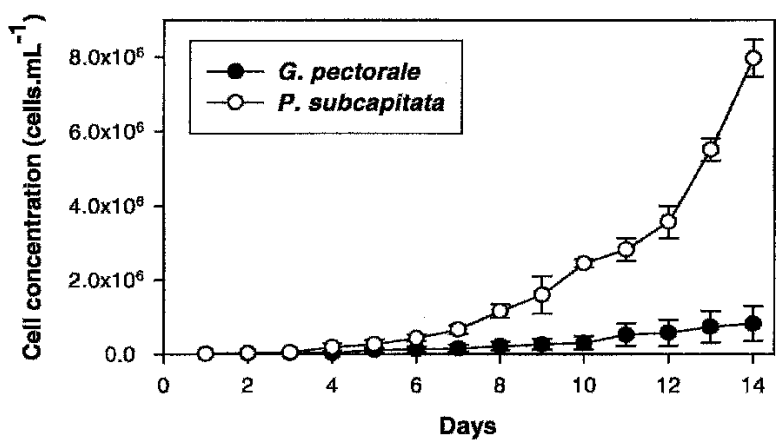

Figure 1. Growth curves of Gonium pectorale Miiller and Pseudokirchneriella subcapitata (Korshikov) Hindak over 14 days. Data are the mean of 3 replicates and error bars represent the standard deviation.

diverse physiological conditions and biological viability. Nevertheless, the results obtained in the present study indicate different sensitivity levels among both tested species to the metals copper, nickel and chromium, revealing the environmental species Gonium pectorale Müller as more sensitive than the laboratory standard species Pseudokirchneriella subcapitata (Korshikov) Hindak (which showed higher levels of $96 \mathrm{hEC}_{50}$ ). Generally, both $P$. subcapitata and G. pectorale proved to be good bioindicators of water quality by showing values of $96 \mathrm{hEC}_{50}$ within or even below (for $\mathrm{Cu}$ ) the range of concentrations found in non-polluted freshwaters

Table 1. Summary of the results ( $96 \mathrm{EC}_{50}$ values) from growth inhibition tests of Pseudokirchneriella subcapitata (Korshikov) Hindak and Gonium pectorale Müller when exposed to the tested metals.

\begin{tabular}{ccc}
\hline & \multicolumn{2}{c}{$96 \mathrm{EC}_{50}$ values $\left(\mathrm{mg} \cdot \mathrm{L}^{-1}\right)$} \\
\hline Metal & $P$. & G. pectorale \\
\hline $\mathrm{Hg}^{2+}$ & - & 0.004 \\
$\mathrm{Cu}^{2+}$ & 0.130 & 0.088 \\
$\mathrm{Cd}^{2+}$ & - & 0.109 \\
$\mathrm{Ni}^{2+}$ & 1.070 & 0.669 \\
$\mathrm{Cr}^{2+}$ & 2.079 & 0.794 \\
$\mathrm{Zn}^{2+}$ & - & 0.983 \\
$\mathrm{Cr}_{2} \mathrm{O}_{7}^{2-}$ & - & 1.218 \\
$\mathrm{Cs}^{+}$ & - & 2.885 \\
$\mathrm{~Pb}^{2+}$ & - & 6.090 \\
\hline
\end{tabular}

in which $\mathrm{Cu}$ generally ranges from 0.20 to $2.00 \mathrm{mg} \cdot \mathrm{L}^{-1}, \mathrm{Zn}$ from 0.50 to 5.00 mg. $\mathrm{L}^{-1}$ and Ni from 0.01 to $1.00 \mathrm{mg} . \mathrm{L}^{-1}$ (de Filippis and Pallaghy 1994). Copper had the highest toxic effect for both algal species, as stated by several authors for other algae (Shehata and Badr 1980; Takamura et al. 1989; Wong and Chang, 


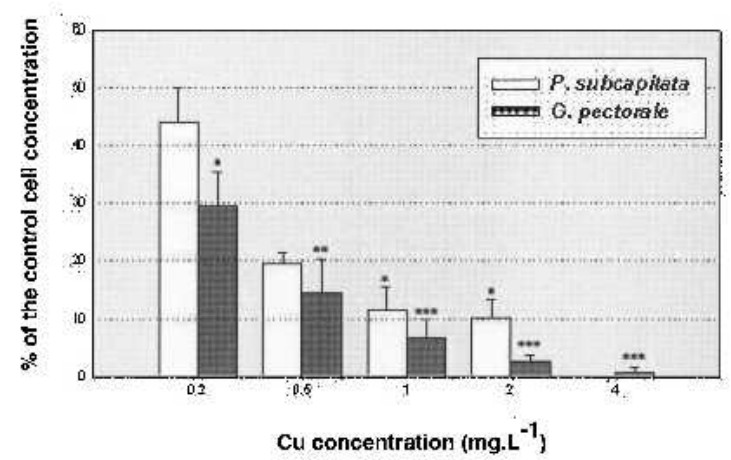

Figure 2. Toxicity of different concentrations of $\mathrm{Cu}^{2+}(0.2,0.5$, $1.0,2.0$ and $4.0 \mathrm{mg} \cdot \mathrm{L}^{-1}$ ) over the growth of $G$. pectorale and $P$. subcapitata after $96 \mathrm{~h}$. Data are the mean of at least 3 replicates and error bars represent the standard deviation. *,** and *** correspond to significant differences compared to $0.00,0.2$ and $0.5 \mathrm{mg} \cdot \mathrm{L}^{-1} \mathrm{Cu}^{2}$, respectively (Tukey test, $\mathrm{P}<0.05$ ).

Figure 3, Toxicity of different

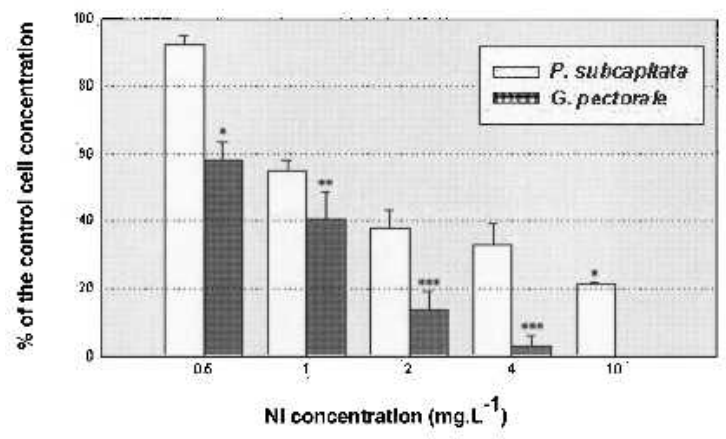
concentrations of $\mathrm{Ni}^{2+}(0.5,1.0$, $2.0,4.0$ and $10.0 \mathrm{mg} \cdot \mathrm{L}^{-1}$ ) over the growth of $G$. pectorale and $P$. subcapitata after $96 \mathrm{~h}$. Data are the mean of at least 3 replicates and error bars represent the standard deviation. *, ** and *** correspond to significant differences compared to $0.00,0.5$ and $1.0 \mathrm{mg} \cdot \mathrm{L}^{-1} \mathrm{Ni}^{2+}$, respectively (Tukey test, $\mathrm{P}<0.05$ ).

Figure 4. Toxicity of different concentrations of $\mathrm{Cr}^{2+}(0.5,1.0$, $2.0,4.0$ and $10.0 \mathrm{mg} \cdot \mathrm{L}^{-1}$ ) over the growth of $G$. pectorale and $P$. subcapitata after $96 \mathrm{~h}$. Data are the mean of at least 3 replicates and егтог bars represent the standard deviation. *, ** and *** correspond to significant differences compared to $0.00,0.5$ and $1.0 \mathrm{mg} \cdot \mathrm{L}^{-1} \mathrm{Cr}^{2+}$, respectively (Tukey test, $\mathrm{P}<0.05$ ).

1991; Danilov and Ekelund 2001). In other studies, Pseudokirchneriella subcapitata (Korshikov) Hindak, when exposed to copper has shown decreased levels of photosynthetic activity (Cvetkovic et al. 199l; West et al. 2003) and presents $\mathrm{EC}_{50}$ values of $0.164 \mathrm{mg.L}^{-1}$ (Rojičková and Maršálek 1999), similar to the one reported in the present study $\left(0.130 \mathrm{mg} \cdot \mathrm{L}^{-1}\right)$. Concerning other green algae, Danilov and Lkelund (2001) stated that using Chlamydomonas reinhardiit the photosynthetic efficiency was stimulated by nickel exposure but zinc and copper 

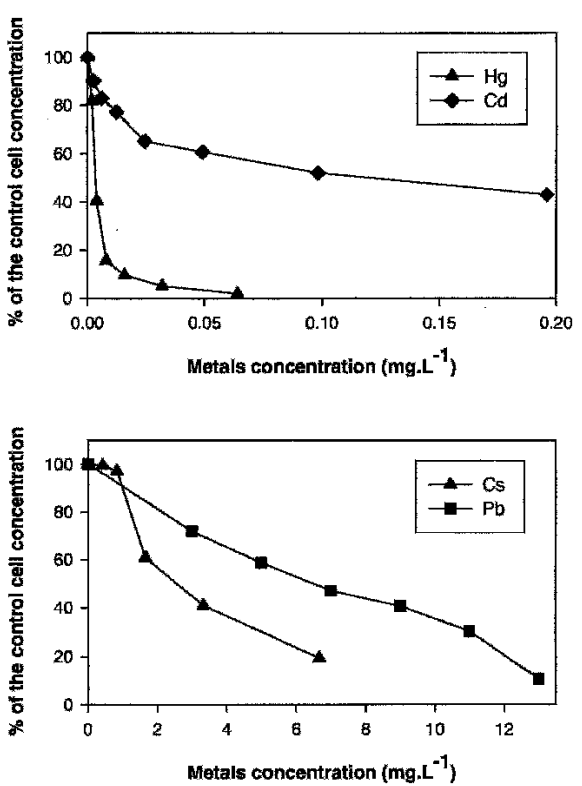

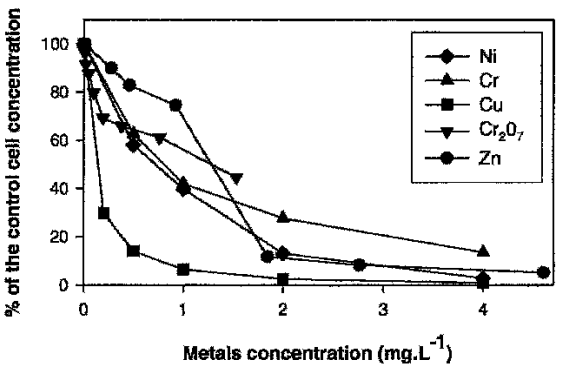

Figure 5. Toxicity of different concentrations of the metals $\mathrm{Hg}^{2+}$, $\mathrm{Cu}^{2+}, \mathrm{Cd}^{2+}, \mathrm{Ni}^{2+}, \mathrm{Cr}^{2+}, \mathrm{Zn}^{2+}, \mathrm{Cr}_{2} \mathrm{O}_{7}^{2-}$ , $\mathrm{Cs}^{+}$and $\mathrm{Pb}^{2+}$ over the growth of $G$. pectorale Müller after $96 \mathrm{~h}$.

were toxic, suggesting the toxic order $\mathrm{Cu}^{2+}>\mathrm{Zn}^{2+}>\mathrm{Ni}^{2+}$. In phytoplanktonic communities, the exposure to heavy metals induces inhibition of algal growth (Starodub et al. 1987; Cvetkovic et al. 1991) and limits cellular survival and reproduction (de Filippis and Pallaghy 1994), acting also on morphologic expression, cellular ultra structure and physiology (Cvetkovic et al. 1991; Mallick and Rai 1992; Danilov and Ekelund 2001) as well as in metabolic and enzymatic activity, avoiding the storage and transformation of the energy (Mallick and Rai 1992). Thus, the different growth responses observed between the two tested species may be partially attributed to different structural and morphological characteristics of several cell constituents (such as the cellular wall).

For $G$. pectorale some more metals were tested and the $96 \mathrm{hEC}_{50}$ values (with the $95 \%$ confidence limits) obtained were $3.72(1.25-9.16) \mu \mathrm{g} . \mathrm{L}^{-1}$ for $\mathrm{Hg}^{2+}, 0.109$ (0.080-0.147) mg. $\mathrm{L}^{-1}$ for $\mathrm{Cd}^{2+}, 0.983(0.439-2.132) \mathrm{mg} . \mathrm{L}^{-1}$ for $\mathrm{Zn}^{2+}, 1.218(0.770-$ $1.926) \mathrm{mg} . \mathrm{L}^{-1}$ for $\mathrm{Cr}_{2} \mathrm{O}_{7}^{2-}, 2.885$ (1.595-5.563) mg.L $\mathrm{L}^{-1}$ for $\mathrm{Cs}^{+}$and 6.090 (2.707$12.400) \mathrm{mg} \cdot \mathrm{L}^{-1}$ for $\mathrm{Pb}^{2+}$ (Table 1 and Figure 5). Thus, the final order of toxicity for all metals tested on $G$. pectorale was: $\mathrm{Hg}^{2+}>\mathrm{Cu}^{2+}>\mathrm{Cd}^{2+}>\mathrm{Ni}^{2+}>\mathrm{Cr}^{2+}>\mathrm{Zn}^{2+}>$ $\mathrm{Cr}_{2} \mathrm{O}_{7}^{2-}>\mathrm{Cs}^{2+}>\mathrm{Pb}^{2+}$. There is a lack of publications concerning the use of Gonium spp. as test organism in growth inhibition tests which limits the comparative analysis of these results. Nevertheless, there are several studies using other green algae to assess the toxicity of metals and those report that, in terms of toxicity: $\mathrm{Cu}^{2+}>\mathrm{Cd}^{2+}>\mathrm{Ni}^{2+}>\mathrm{Zn}^{2+}>\mathrm{Pb}^{2+}$ (Shehata and Badr 1980), $\mathrm{Cu}^{2+}>\mathrm{Zn}^{2+}$ $\gg \mathrm{Pb}^{2+}$ (Starodub et al. 1987), $\mathrm{Cu}^{2+}>\mathrm{Cd}^{2+}>\mathrm{Zn}^{2+}$ (Takamura et al. 1989), $\mathrm{Cu}^{2+}$ $>\mathrm{Cr}^{2+}>\mathrm{Ni}^{2+}$ (Wong and Chang 1991), $\mathrm{Cu}^{2+}>\mathrm{Ni}^{2+}>\mathrm{Fe}^{2+}$ (Mallick and Rai 1992) and $\mathrm{Cu}^{2+}>\mathrm{Cr}_{2} \mathrm{O}_{7}^{2-}>\mathrm{Zn}^{2+}$ (Rojičková and Maršálek 1999). $\mathrm{Hg}^{2+}$ has proved to be the most toxic tested metal for $G$. pectorale. The extremely toxic effects of mercury have been reported for other algae such as the cyanobacterium Spirulina 
platensis (Lu et al. 2000), by inhibiting its photosynthetic performance. In general, copper is highly toxic and lead is poorly toxic. The photosynthetic efficiency (PE) is a physiological parameter that follows this toxicity with copper highly inhibiting photosynthesis in other algae (Nalewajko and Olaveson 1995; Danilov and Ekelund 2001) while nickel and lead have low toxicity and may even have stimulatory effects (with the highest values for $1.5 \mathrm{mg} \cdot \mathrm{L}^{-1}$ ) on the $\mathrm{PE}$ of the motile Chlamydomonas reinhardtii (Danilov and Ekelund 2001). The differences observed between different authors for the other metals could be due to different assay conditions, test organism physiology and tested substance. By the results presented in this paper, G. pectorale proved to be appropriate to perform low cost static test because its mobility avoids problems of algal sedimentation by filling the whole tested volume, including the interface water-air, an ecological niche that has not received much attention in ecotoxicology. This capacity to occupy the whole tested volume also gives the possibility to detect the toxicity of colored toxic effluents. As mentioned above, there are not many growth inhibition tests using Gonium spp. but by their higher sensitivity and dispersion all over the test medium, these flagellate coenobium species may be an important alternative to the standard species used as test organisms for chemicals. However, more studies with other algal species and a wider range of toxicants must be done to clarify this higher sensitivity of G. pectorale.

Acknowledgments. We thank to Dr. Bruno Branco for his support with the statistical program during the analysis of assays data.

\section{REFERENCES}

Andersen MK, Raulund-Rasmussen K, Strobel BW and Hansen HCB (2002) Adsorption of Cadmium, Copper, Nickel, and Zinc to a Poly(tetrafluorethene) Porous Soil Solution Sampler. J Environ Qual 31: 168-17

Boullemant A, Vigneult B, Fortin C, Campbell PGC (2004) Uptake of Neutral Metal Complexes by a Green Alga: Influence of $\mathrm{pH}$ and Humic Substances. Australian J Chem 57: 931-936

Campanella L, Cubadda F, Sammartino MP, Saoncella A (2001) An algal biosensor for the monitoring of water toxicity in estuarine environments. Water Res 35: 69-76

Cervantes C, Campos-García J, Devars S, Gutiérrez-Corona F, Loza-Tavera H, Torres-Guzmán JC, Moreno-Sánchez R (2001) Interactions of chromium with microorganisms and plants. FEMS Microbiol Rev 25: 335-347

Cvetkovic AD, Samson G, Couture P, Popovic R (1991) Study of dependency between culture growth and photosynthetic efficiency measured by fluorescence induction in Selenastrum capricornutum inhibited by copper. Ecotoxicol Environ Saf 22: 127-132

Danilov RA, Ekelund NGA (2001) Effects of $\mathrm{Cu}^{2+}, \mathrm{Ni}^{2+}, \mathrm{Zn}^{2+}$ and pentachlorophenol on photosynthesis and motility in Chlamydomonas reinhardtii in short-term exposure experiments. BMC Ecol 1: 1 
de Filippis LF, Pallaghy CK (1994) Heavy Metals: sources and biological effects. In: Rai LC, Gaur JP, Soeder CJ (eds) Algae and Water Pollution. E. Schweizerbart'sche Verlagsbuchhandlung, Stuttgart, 31-77

Fleeger JW, Carman KR, Nisbet RM (2003) Indirect effects of contaminants in aquatic ecosystems. Sci Total Environ 317: 207-233

Kennish MJ (1992) Ecology on estuaries: anthropogenic effects. CRC Press, Boca Raton, 494 pp.

Lu CM, Chaw CW, Zhang JH (2000) Acute toxicity of excess mercury on the photosynthetic performance of cyanobacterium, $S$. platensis - assessment by chlorophyll fluorescence analysis. Chemosphere 41: 191-196

Mallick N, Rai LC (1992) Metal induced inhibition of photosynthesis, photosynthetic electron transport chain and ATP content of Anabaena doliolum and Chlorella vulgaris: interaction with exogenous ATP. Biomed Environ Sci 5: 241-250

Meylan S, Behra R, Sigg L (2003) Accumulation of copper and zinc in periphyton in response to dynamic variations of metal speciation in freshwater. Environ Sci Technol 37: 5204-5212

Nalewajko C, Olaveson MM (1995) Differential responses of growth, photosynthesis, respiration, and phosphate-uptake to copper in copper tolerant and copper-intolerant strains of Scenedesmus acutus (Chlorophyceae). Can J Bot 73: 1295-1303

Rojičková R, Maršálek B. (1999) Selection and sensitivity comparisons of algal species for toxicity testing. Chemosphere 38: 3329-3338

Shehata SA, Badr SA (1980) Growth response of Scenedesmus to different concentrations of copper, cadmium, nickel, zinc, and lead. Environ Int 4: 431434

Starodub ME, Wong PTS, Mayfield CI (1987) Short term and long term studies on individual and combined toxicities of copper, zinc and lead to Scenedesmus quadricauda. Sci Total Environ 63: 101-110

Takamura N, Kasai F, Watanabe MM (1989) Effects of $\mathrm{Cu}, \mathrm{Cd}$ and $\mathrm{Zn}$ on photosynthesis of freshwater benthic algae. J Appl Phycol 1:39-52

Wei L, Donat JR, Fones G, Ahner BA (2003) Interactions between $\mathrm{Cd}, \mathrm{Cu}$, and $\mathrm{Zn}$ influence particulate phytochelatin concentrations in marine phytoplankton: laboratory results and preliminary field data. Environ Sci Technol 37: 3609 . 3618

West LJA, Li K, Greenberg BM, Mierle G, Smith REH (2003) Combine effects of copper and ultraviolet radiation on a microscopic green alga in natural soft lake waters of varying dissolved organic carbon content. Aquat Toxicol 64: 39-52

Wong P-K, Chang L (1991) Effects of copper, chromium and nickel on growth, photosynthesis and chlorophyll $a$ synthesis of Chlorella pyrenoidosa 251 . Environ Pollut 72: 127-139

Yan H, Pan G (2002) Toxicity and bioaccumulation of copper in three green microalgal species. Chemosphere 49: 471-476

Zar JH (1996) Biostatistical Analysis. Prentice-Hall International, Inc., New Jersey, $662 \mathrm{pp}$. 